University of South Florida

DIGITAL COMMONS

Digital Commons @ University of

@ UNIVERSITY OF SOUTH FLORIDA

South Florida

School of Interdisciplinary Global Studies

Faculty Publications

Fall 2016

\title{
Is China Playing a Contradictory Role in Africa? Security Implications of its Arms Sales and Peacekeeping
}

\author{
Earl Conteh-Morgan \\ University of South Florida, conteh@usf.edu \\ Patti Weeks \\ University of South Florida
}

Follow this and additional works at: https://digitalcommons.usf.edu/sigs_facpub

\section{Scholar Commons Citation \\ Conteh-Morgan, Earl and Weeks, Patti, "Is China Playing a Contradictory Role in Africa? Security Implications of its Arms Sales and Peacekeeping" (2016). School of Interdisciplinary Global Studies Faculty Publications. 19. \\ https://digitalcommons.usf.edu/sigs_facpub/19}

This Article is brought to you for free and open access by the School of Interdisciplinary Global Studies at Digital Commons @ University of South Florida. It has been accepted for inclusion in School of Interdisciplinary Global Studies Faculty Publications by an authorized administrator of Digital Commons @ University of South Florida. For more information, please contact digitalcommons@usf.edu. 


\section{Global Security and Intelligence Studies}

Volume 2

Number 1 Fall 2016

Article 7

2016

Is China Playing a Contradictory Role in Africa? Security Implications of its Arms Sales and Peacekeeping

Earl Conteh-Morgan

University of South Florida

Patti Weeks

University of South Florida

Follow this and additional works at: http://digitalcommons.apus.edu/gsis

Part of the African Studies Commons, Defense and Security Studies Commons, and the International Relations Commons

\section{Recommended Citation}

Conteh-Morgan, Earl and Weeks, Patti (2016) "Is China Playing a Contradictory Role in Africa? Security Implications of its Arms Sales and Peacekeeping," Global Security and Intelligence Studies: Vol. 2 : No. 1 , Article 7.

Available at: http://digitalcommons.apus.edu/gsis/vol2/iss1/7 


\section{Is China Playing a Contradictory Role in Africa? Security Implications of its Arms Sales and Peacekeeping}

\section{Earl Conteh-Morgan ${ }^{\mathrm{A}} \&$ Patti Weeks ${ }^{\mathrm{B}}$}

This article offers a critical analysis of the conflict and regional security implications of one of the strategies (arms sales) utilized by China to expand and consolidate its presence in Africa. This worrying trend is juxtaposed against its equally increasing peacekeeping and peacebuilding activities in post-conflict states within the continent. The analysis, accordingly, argues that the simultaneous growth in the scope of arms transfers and increase in contributions to peacekeeping and peacebuilding activities is tantamount to a contradictory policy toward Africa. Arms sales to African states encourage some incumbent regimes to maintain their despotic and oppressive rule thereby increasing the probability of violent conflicts between regimes and opposition groups. Small arms also prolong civil wars because of the easy access to them. While Chinese arms have been implicated in many conflicts in Africa, China at the same time is also enhancing African Union peacekeeping activities through generous financial donations as well as participation in humanitarian assistance, national police training, and resettlement of ex-combatants, among other activities. The question is, why does China pursue these seemingly antithetical policies within Africa? Or, why does China play this contradictory role contrary to its narrative of noninterference in the internal affairs of other states?

Keywords: China, Africa, Arms Sales, Peacekeeping, Peacebuilding.

\section{Introduction}

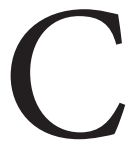

Thina's growing presence in Africa has spawned many explanations of its political, economic cultural and other activities in the continent. A good deal of its interactions with African states involves arms sales and support for peacekeeping and peacebuilding activities. In its dealings with African states it deliberately tries to set itself apart from the West's record of colonial rule and exploitation of the continent. China constantly reiterates and underscores its foreign policy of noninterference in the affairs of African states. Nonetheless, it has not been able to escape the lure of the benefits that are associated with arms sales to Africa, plus its negative consequences, as well as the geopolitical ties that it enhances between China and Africa. Accordingly, the objective of this article is to analyze China's seemingly contradictory

${ }^{\text {A }}$ Professor, School of Interdisciplinary Global Studies, University of South Florida

${ }^{\text {B }}$ Adjunct Professor, Department of History and Political Science, University of South Florida doi: 10.18278 /gsis.2.1.6 
arms transfers/military relationships with African countries and simultaneous active engagement in peacebuilding activities in African countries where its weapons have been implicated in bloodletting and war crimes in general. In other words, what are the geopolitical and geo-economic rationales for increasing Chinese arms transfers and military relationships with African nations in contrast to its contributions to UN peacebuilding efforts and support for African peacekeeping activities? How do arms transfers to African nations and involvement in peacebuilding activities portray China as playing contradictory roles in Africa? What are the conflict and peace implications for African countries of these seemingly contradictory activities by China?

For a long time, arms transfers to Africa have been dominated by the US, Britain, France, and Russia (Grant 2012; Pierre, 1982. However, recent trends in Chinese industrialization and China's growing scope of political, economic, and diplomatic activities may suggest that a fundamental shift in arms transfers to Africa may be occurring that, over time, could have important consequences for increased internal wars or peacekeeping operations in the continent.

The literature on arms transfers has long suggested that arms transfers to developing countries tend to widen the scope of violence and even intensify or increase the duration of wars thereby making the maintenance of peace more difficult (Klare 2014; Sanders 1990; Schelling 2008). At times bilateral arms transfer relationships take the added form of arms production, whereby the supplier sets up arms production facilities in the recipient country.

\section{Reasons for Antithetical Policies}

7 he primary reason why China pursues these seemingly antithetical policies in Africa is found in its overall geo-strategy in the continent. This geo-strategy is a combination of geopolitical and geo-economic policies. The latter refers to the economic objective of ensuring access to Africa's strategic resources, while the former refers to consolidating political ties with all African states, especially with the politically important ones. First, China sees African states such as Kenya, South Africa, Ethiopia, the Democratic Republic of Congo, Nigeria, and Zimbabwe, among others, as countries with which to engage in lucrative trade (hence arms sales) as part of its geo-economic rivalry with the West. At the same time there are countries in Africa that need peacebuilding and peacekeeping assistance because of ongoing civil wars or postwar reconstruction. Accordingly, China participates in both peacekeeping and peacebuilding activities which help to strengthen its geopolitical ties with these African states. These humanitarian activities present opportunities for China to put into practice its frequent pronouncements that it is a friend of Africa.

China's policy of non-interference in human rights within the recipient country makes it an attractive and willing source of weapons for African countries. Since many African countries attempt to break free of Western rules and regulations about arms procurement, they turn to China which does not burden them with external impositions associated with arms transfers and production, such as human rights, or democratic ideals. Besides, where an arms production facility/factory is set up within 
a developing country, it tends to bolster morale and a sense of independence and autonomy in military hardware. In other words, a domestic arms production facility reduces a country's dependence on more developed countries. More arms production autonomy inevitably means less dependence on major suppliers, at least, for small arms or light weapons. Moreover, apart from the determination by African countries to lessen dependence on Western suppliers, they also want to ensure reliability and consistency of supply. The major arms suppliers often impose embargos on arms sales to countries whose policies they find objectionable. For instance, the US often makes human rights issues a key criterion in determining US military aid and sales. China, on the other hand, does not use human rights and democracy as criteria for transferring arms to African countries. Many resolutions are passed in the UN Security Council, or by Western governments barring the sale of weapons to governments engaged in wars against rebel groups or neighboring states. Furthermore, China's Africa policy is also one that provides benefits and employment opportunities for skilled Chinese citizens (Baah and Jauch 2009; Lynch 2012). This is an example of China's geo-economic objective in Africa. By establishing arms factories, and training Africans to use the more sophisticated weapons they supply, skilled Chinese such as scientists, engineers, and industrial managers are offered more opportunities for applying their skills and knowledge. The interaction between African and Chinese skilled workers, it is hoped, would produce better understanding between the two in competition with the West. In addition, China's arms industry, just as the arms industries of other nations, is designed to be both a military and economic asset. For an arms industry to be sustainable it has to be profitable, thus the need for arms exports to other nations. The revenue generated from arms exports feeds into research and development for new and better weapons systems. This is especially the case with China where the government with its State Owned Enterprises (SOEs) is the key, if not the sole, exporter of weapons to developing countries (SIPRI 2011). Arms exports are therefore an economic imperative, and a sine qua non for maintaining an arms industry. Besides, Chinese arms find a ready market in some African countries that consider themselves, or would like to be perceived as regional influentials. Countries such as Nigeria in West Africa, Kenya in East Africa, or the Democratic Republic of Congo (DRC), and South Africa, among others, fall into this category. Still others import Chinese arms in order to feed the conflicts in the DRC, Sudan, Central African Republic, among others. While arms transfers during the Cold War were predicated largely on the need to supply warring factions in civil wars, or proxy wars, or post-independence struggles for power, today regime survival or incumbent regime efforts fuel arms transfers. The coercive military balance between regime and dissidents is determined largely by the access to a steady supply of weapons.

The Chinese arms transfer rationales have undergone change in response to changes in power political and economic competition in the international system (Caldwell 2015). In particular, during the era of political ideological rivalry between communism and capitalism, China supplied weapons to both state and non-state revolutionary actors with the aim of bolstering Maoism and China's national interests. The focus was largely ideological and not motivated by profit. Currently, in this era 
of economic globalization and commercial competition, Chinese arms serve more of a profit motive (Mullen 2016). In its arms relationship with African nations, arms sales have more commercial and political bases and thereby promote both the geoeconomic and geopolitical goals of Africa.

\section{China's Multidimensional Approach in Africa}

$\mathrm{T}$ his analysis focuses on China's contradictory policies of arms sales/military cooperation and peacebuilding/peacekeeping activities in African nations. to sub-Saharan African nations. However, while arms sales and peacebuilding activities may seem contradictory policies, they are an integral aspect of China's multidimensional approach to Africa which includes activities such as agriculture and health training, educational cooperation, mineral investments, infrastructure development, telecommunications services, and military cooperation, among many others. This approach has inevitably led to the seeming contradictions between the simultaneous expansion of arms sales and peacekeeping activities. In fact for a long time, the foremost arms suppliers to Africa have been the US, France, Britain, and Russia. In terms of largest world arms suppliers, China was for a long time not among the five top global suppliers. It was only in 2010 that it ranked among the top five suppliers occupying the position of third largest weapons supplier (SIPRI 2011). China has realized that in order to achieve its geo-strategic and economic ambitions it needs to be more competitive with the leading arms suppliers, the US, Britain, Germany, France, and Russia. Its increasing competitiveness may in large part be due to its arms sales to sub-Saharan African states. Its ongoing geo-political and economic objectives in African countries have, at the same time, widened and even strengthened its arms trade with African states.

China's growing penchant for increasing its arms sales to Africa is driven by both domestic factors as well as external imperatives of economic globalization-in this latter case is the need to compete with the foremost global arms suppliers, the US, France, Russia, Britain, and Germany in particular. The domestic factors that may be largely responsible for China's arms transfer to Africa are: (1) the Chinese state's inability to regulate or monitor all arms exports from China; (2) China's arms sales to African nations of geopolitical and geo-economic importance to China in Africa, such as Sudan and Zimbabwe; and (3) the freedom of trade that comes with economic liberalization in China which has spawned many private enterprises, some of which are engaged in arms transfer purely for the profit motive. These internal-external factors responsible for China's arms transfer to Africa are driven by what could be referred to as the globalization imperative. This last reason is directly related to the fact that many Chinese enterprises with close ties to the People's Liberation Army (PLA) no longer benefit from that symbiotic relationship. The (PLA) formally divested itself from commercial operations after Jiang Zemin called for the dissolution of China's military-business complex (Hyer 1992; Taylor and Wu 2012). Military acquiescence to divestiture was contingent on generous compensation from Beijing as well as allowing 
the PLA to pursue profits via arms sales. Accordingly, it currently exercises strong influence over defense-related enterprises and searches for its own arms export markets. The exposure of defense companies to more independent commercial management is driven by the need for China to compete with the major arms suppliers. Most of the profits earned remain with these companies while a portion goes to the Ministry of Finance. The result is that the PLA no longer receives profits from civilian enterprises and now relies to a large extent on arms sales. The need to increase profits from arms sales result in selling weapons that escape the scrutiny of the state. Consequently, the vigorous search for markets in Africa is the result of necessity by the PLA to regain its lost domestic commercial profits via external commercial arms relationships.

The dissolution of China's military business complex, it could be argued was a deliberate policy to ensure that the country becomes more competitive in arms sales relative to other major powers. What the policy did, is to privatize its arms industry and open it to domestic competition among Chinese firms. Many of China's privately owned firms entered the African market and thereby acted as competitors to firms from other major countries. However, because of China's non-conditional policy of arms sales, it was not long before Chinese weapons were implicated in atrocities in Sudan, especially Darfur, the Democratic Republic of Congo, in Liberia, and Zimbabwe, among others. In order to quell the growing negative image of itself in Africa because of its support of despotic regimes through arms sales, it expanded its peacekeeping and peacebuilding activities in the continent. Its involvement in increased peacekeeping was also a reaction to calls on it to be a more responsible partner in the international system. In other words, while China is searching for commercial opportunities in Africa, at the same time, it wants to preserve a good image in the world. It does not want to be seen as the enhancer of genocides, authoritarian regimes, or supporter of despots in the African continent. China attempts therefore to skillfully balance weapons sales with an expanding peacebuilding agenda in order to silence some of the criticism directed at it by the West.

African nations can be categorized into two broad categories, those that are of geopolitical importance such as Nigeria, South Africa, Kenya, and Ethiopia. These are sometimes referred to as anchor states. They could also be referred to as sub-regional hegemons. In Africa, these four states exercise considerable influence within their regions. They are characterized by a substantial power base relative to others within the same region. They often have a stronger and larger military, a larger population, and larger geographic size, critical raw materials, and a strategic location, relative to the many small African nations. They sometimes aspire to regional hegemony and could become directly involved in the foreign policy and economic goals of major powers. In sub-Saharan Africa, Nigeria, South Africa, Kenya, in particular generally possess many or all of the geo-strategic and geo-economic characteristics of subregional influentials. For instance, has the geo-economic and geo-strategic importance of Nigeria correlated strongly with Chinese arms transfers to that country? Nigeria as a sub-regional hegemon or anchor state in West Africa receives regular military assistance and arms transfer from China. The military ties between Nigeria and China are regularly cemented by reciprocal visits at the level of Defense Ministers. In June 
2004, Nigeria's defense minister paid a state visit to China. China reciprocated by, among other things, agreeing to supply new combat jets to Nigeria, signing a contract with Nigeria's defense ministry worth over $\$ 250$ million to transfer 15 Chengdu F/FT7NI aircrafts in 2005 (Chau 2007). Transfers of sophisticated Chinese arms are usually followed by training of African military personnel on how to use them. Accordingly, in 2006 several Nigerian pilots traveled to China to undergo training on the use of the new aircrafts. In addition to the transfer of aircrafts, China also transferred air-to-air missiles, rockets, and anti-tank bombs, among others, worth $\$ 32$ million. Between 2004 and 2006 other arms transfer or military assistance agreements between China and Nigeria were worth over $\$ 70$ million involving supplies of patrol boats, trainer and fighter aircraft, and military transports. There are several other examples of China cementing its relationship with African countries through military assistance. Among the many examples is China's donation of $\$ 43$ million worth of military equipment to Nigeria in October 2005. The equipment ranged from uniforms, communication technology, bullet proof helmets and vests, to computers, among other things (Enuka 2011). China did not just transfer this equipment to Nigeria, but the transfer was later followed by several Chinese military experts whose mission was to train Nigerian military personnel on how to use the donated equipment.

Within the past decade, the 10 African countries with the highest level of military cooperation with China are Algeria, Angola, Egypt, Ghana, Nigeria, South Africa, Sudan, Uganda, Zambia, and Zimbabwe (Alessi and Xu 2015). Although the value of arms transfers from China to Africa could be described as modest compared to trade in oil and other commodities, military interactions are carried out through high level political delegations, while arms transfers and high level bilateral ties are used as instruments to help secure more economic access to critical raw materials. Since the end of the 1990s high level military delegations have been a regular occurrence between Beijing and several African countries. Of the 10 countries engaged in high levels of military cooperation with China, six of them are either suppliers of oil, gas, and other critical resources, or they have substantial Chinese commercial investments. This places China-Africa weapons transfers and military cooperation into two distinct dimensions: (1) countries with strategic minerals like Sudan and Nigeria, and South Africa, and the Democratic Republic of Congo; and (2) anchor states/regional influentials/sub-regional hegemons like South Africa, Nigeria, Kenya, and Ethiopia, among others. In some cases there is an overlap between the two where geo-economic countries like Sudan, Nigeria, and South Africa are also regional hegemons.

\section{China's Arms Sales Strategy to Africa}

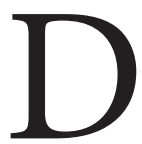
uring the 1990s, Chinese weapons were considered to be substandard in firepower and offensive capability vis à vis the most simplistic, low-tech military armaments available, and limited to a defensive capacity, having only "nuisance value" (Bitzinger 1991). Consequently, Chinese weapons exports were limited to less than $10 \%$. However, Chinese arms sales, especially in Africa, have increased. China has aggressively marketed its weapons to poorer and less technologically advanced 
African states because of its inability to compete for sales in the more technologically advanced arms markets dominated by the US, Britain, France, and Russia.

China's aggressive arms sales in African markets have placed it among the top five arms suppliers in the world. It currently has arms transfers deals or military relationships with several large African states such Egypt, Nigeria, Ethiopia, Zimbabwe, and South Africa, as well as smaller states like the Republic of Congo, Equatorial Guinea, Eritrea, Burundi, and Sierra Leone, among others. One of the strategies utilized by China to make its arms sales attractive is the use of favorable financing. Many African countries cannot afford expensive, sophisticated weapons that fetch premium prices in the international marketplace. So China caters to this market, making its weapons affordable to cash poor countries through loans with very low interest rates or mineral rich countries willing to grant access to natural resources in a quid pro quo arrangement for supplying weapons. Consequently, the cost of Chinese made weapons remains below market, giving China the competitive edge through affordability, defined as inexpensive, rather than affordability defined as sophistication (Baker 2015). This translates into poor African countries having easy access to small, inexpensive, easy-to-use arms from China that have the potential to fuel eruptions of instability, increase political repression, and stifle economic development in recipient countries. This strategy by China has the dual effect of strengthening its ties with authoritarian leaders who need weapons to perpetuate their rule, and benefiting from sales to these authoritarian regimes thereby achieving its geo-economic objectives. China, stated differently, is using a "catch all" strategy in its dealings with African states. Moreover, China uses frequent and aggressive marketing tactics to capture market share in Africa, constantly promoting its military hardware at annual arms exhibits held in various states spanning the continent. The list of cooperating Chinese manufacturing firms is lengthy and includes companies such as China National Electronics Import-Export Corporation (CEIEC), China Electronics Technology Corporation (CETC) International, and China Aviation Industrial Base Corporation (CAIBC), as well as hundreds of smaller manufacturers. Apart from a strategy of affordability through attractive financing and payment options, China also ensures a wide array of arms and military hardware in its export inventory. Consequently, the scope of its offerings include small arms, armored vehicles, tactical and air defense weapons, naval ships, short range tactical ballistic missiles fighter jets, and communications surveillance and reconnaissance equipment. The list of available equipment also includes uniforms, boots and packs, as well as police items such as protective clothing and riot gear. Variation in wealth and military strength among African countries allows China to sell both small inexpensive, low-tech weapons as well more expensive and sophisticated military weapons. Consequently, transfers include battle tanks, guided missiles, air defense systems, and armored personnel carriers. Furthermore, China's success in African markets is also enhanced by its long standing policy of non-interference. This policy has allowed China, on occasion, to sell weapons to opposing warring entities as was the case in the Ethiopia-Eritrean conflict. Similarly, Chinese weapons were used in the Darfurian genocide in the Sudan where Janjaweed militia systematically murdered, raped, and tortured civilians (Enuka 2011). 
Once established, the arms transfer relationship between China and its African trading partner becomes reinforced by the recipient who will be in constant search of spare parts, ammunition supply, maintenance upgraded technology, and weapons training which may take place in Africa or China. Although Chinese arms sales in Africa is small relative to transfers with the more traditional suppliers and former colonial powers of Britain and France, as well as the leading arms suppliers of Russia and the US, Chinese arms sales in Africa attract particular attention and criticisms because: (1) its arms transfers to states of international concern such as Sudan and Zimbabwe; (2) its willingness to supply arms to any country in Africa with an ability to pay for them; and (3) the contradiction between its long-standing policy of non-interference and its practice of supplying arms to warring factions within a sovereign nation. Arming sectarian combatants within a sovereign nation is inherently interventionist in nature and unequivocally interference in a country's internal affairs, especially when that country is in the throes of civil war, and where civilians have experienced gross human rights violations.

\section{Chinese Arms: Negative Impact on African Conflicts}

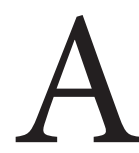

lthough the value of arms transfers from China to Africa could be described as modest compared to trade in oil and other commodities, high-level military interaction and high-level political delegations have succeeded in enhancing China's access to critical raw materials in Africa (Hyler 1992). Since the end of the 1990s, military delegations have been a regular form of interaction between China and African countries. Arms transfers and military cooperation between China and African nations fall into two categories: (1) countries with strategic minerals like Sudan and Nigeria. These are geo-economically important countries to China in particular; and (2) key states like Nigeria, Kenya, South Africa, Ethiopia, the DRC, Ghana, and Zimbabwe, among others. Generally, many African states find China an attractive arms trading partner because of its "no strings attached" approach to transfer. China does not make its weapons sales conditional on either human rights or democratic reforms.

China is currently a key supplier of conventional weapons in Africa where arms transfers there inevitably contribute to civil strife and carnage in more than a few local conflicts. It is generally alleged that the light weapons used in the massacres in eastern DRC were Chinese. There, children as young as 11 years old were given weapons by warlord Thomas Lubanga, and forced to take part in brutal ethnic fighting between 2002 and 2003 (SAFERWORLD 2011). Moreover, according to Amnesty International reports, in February 2012, both Russian and Chinese supplied weapons fueled conflict in Sudan. In particular, arms transfers such as helicopter gunships, attack aircraft, airto-air ground rockets and armored vehicles, including ammunition, are responsible for serious human rights violations in Darfur, Sudan. Small arms of Chinese manufacture were used by the Sudan Armed Forces (SAF) and government supported militia, including Sudan's Popular Defense Force (PDF) to carry out atrocities in Darfur. While all of the carnage cannot be directly attributed to Chinese supplied arms as other countries were active in supplying weapons as well, it is important to note that 
an estimated 70,000 people were displaced from eastern Darfur in 2011 due to ethnic attacks directed toward the Zarghawa community by the SAF and government-backed militias. Nevertheless, Amnesty International confirmed that Chinese-made weapons are found all over Sudan including Southern Kordofan (Deen 2012).

In December 2011, a SIPRI report found that by 2010 China was the foremost exporter of arms to Africa, a continent well known for gross human rights violations. Between 2006 and 2010 China had captured a full $25 \%$ of the market compared to only 9\% in the preceding 5 year period between 2001 and 2005 (SIPRI 2011). The reason for China's leading role in arms transfers over traditional leaders like the US, Russia, France, Germany, and the UK, is the fact that it is willing to transfer military aid or make more attractive deals in exchange for critical resources rather than cash. Moreover, China is also prone to ignore UN sanctions against arms trade with countries like Sudan or Zimbabwe where severe human rights violations occur. However, some critics believe that China's arms transfer role in Africa is exaggerated by Western countries noting that while China transfers largely small or light weapons, exporters like the US focus on quality transferring more sophisticated weapons, while Russia concentrates on quantity, making it the largest arms supplier to Africa. China takes much of the blame because it supplies small, low-tech, arms which are relatively inexpensive and easy to use and as a result, cause more destruction because of their scope and frequency of use compared to more sophisticated heavy weapons. Small or light arms are also responsible for civil unrest, atrocities, civilian deaths and involvement of child soldiers in rebellions. It is much easier to use a Chinese Type 56 rifle (China's version of the Russian Avtomat Kalashnikov (AK) assault rifle) than a Chinese aircraft which would require specialized training before it could be operated. China is viewed as playing a contradictory role where arms transfers and peace-keeping are concerned. For example, in the case of Sudan, China finally submitted to pressure to support UN Peacekeeping, but at the same time failed to suspend its arms sales which negatively impacted the regions of Darfur, South Kordofan, and the Blue Nile. China is, in other words, not interested in joining an arms embargo, or unilaterally ending arms sales in zones of conflict in Africa. China, one could argue, is a captive of its own foreign policy doctrine of non-interference in the affairs of another country (McPartland 2012).

Chinese exports to Sudan comprise of attack aircraft, munitions, and armored vehicles which are used against civilians. According to Amnesty International, following a raid at the Zam Zam camp for displaced civilians in Sudan in December 2011, ammunition was discovered bearing Chinese " 41 " and " 71 " manufacture codes, and (20) 06 and (20) 08 manufacture dates indicating that it was transferred to Darfur after the imposition of a UN arms embargo (Amnesty International 2012). China's violation of the UN arms embargo on Sudan is evident throughout the country with Chinese made ammunition bearing its own manufacture codes discovered in Darfur and the South Kordofan regions in 2011. Using either Chinese or Russian-made weapons, the SAF has focused its attacks on both military targets and civilian populations. In 2009, Chinese-trained Guinean Commando units were responsible for the killing of about 150 people during a protest against authoritarian rule in Conakry. In eastern DRC, Chinese trained Congolese troops were implicated in the killing of many innocent 
civilians demonstrating that an increase in Chinese arms transfers to Africa is likely associated with more strife and bloodletting.

While China is largely known for its sale of small weapons and the human carnage left in their wake in places like Sudan and the DRC, the Chinese are also active in supplying sophisticated weapons to oil-rich African states including armored vehicles, artillery, jet fighters, and training and transport aircraft. China's sophisticated weapons transfers to Sudan include F-6 and F-7 fighter aircraft, light tanks, and antiaircraft systems. Zimbabwe was the recipient of nine J-7 fighter aircraft and six K-8 trainer aircraft as well as 10 T-69 tanks and 30 T-59 tanks. Nigeria has expanded its assets with its US\$251 million purchase of 15 F-7 fighter aircraft (Young 2016). And Angola ordered eight Su-27 fighter aircraft. Transfer of This sale corresponded very strongly with the fact that in 2005 Angola exported 17.5 million tons of crude oil to China becoming China's largest oil supplier by 2006. Chinese arms transfers are strongly associated with oil and trade agreements with geo-economically important countries such as Angola, Nigeria, Gabon, Equatorial Guinea, and the DRC, among others. Angola is surpassed only by Sudan as China's most geo-economic trading partner in Africa. Sudan has been the recipient of more Chinese made weapons and military equipment such as cargo trucks, battle tanks, and transport aircraft. These are in addition to mortars, rocket launchers, and air defense systems (Chang 2007). The level of sophistication of Chinese arms transferred to Sudan is strongly associated with Sudan's geo-economic importance to China. China is the recipient of more than, or approximately, $90 \%$ of Sudan's oil exports. China's military presence in Sudan is quite substantial, with over 4000 Chinese military personnel in the country to protect its extensive and multi-billion dollar oil infrastructure investments (Human Rights First 2008).

Zimbabwe is not oil rich, but endowed with a variety of critical minerals that China needs in its industrialization efforts. Accordingly, Zimbabwe has been the recipient of small arms and ammunition and sophisticated weaponry such as different types of armored fighting vehicles, and jet aircrafts. Moreover, China supplied the Mugabe regime instruments of opposition control such as radio-jamming equipment to disrupt opposition party broadcasts, and riot control equipment to suppress protests and demonstrations. In particular, oil-rich or strategic mineral endowed countries are the recipients of millions of dollars in Chinese investments, including military assistance or arms sales. The Republic of Congo is also rich in oil and supplies China with approximately $5 \%$ of its oil requirements. Congolese military forces are armed with major Chinese weapons such as the Type 59 tanks, Type $63107-\mathrm{mm}$ rocket launchers, Type $60122-\mathrm{mm}$ howitzers, and Type $59130-\mathrm{mm}$ cannons. This is in addition to various types of Chinese light weapons. Critics argue that China ignores the UN international arms embargo on Congo and continues to sell weapons to the country.

Other geo-economic African countries such as Egypt, Algeria, Nigeria, the DRC, and the like have received weapons systems such as the K-8 trainer aircraft, the J-7 fighter aircraft, training ship, missile fast craft with C802 ship-to-ship missiles. States that are not so geo-economic such as Mauritania, Zambia, Namibia, Eritrea, 
Burundi, and Tanzania, all receive weapons systems from China. The transfer of weapons is inevitably accompanied by the dispatch of technical advisors by China, or the training of African military personnel in China. China in addition, maintains military attaches in some African nations such as Algeria, the DRC, Egypt, Ethiopia, Liberia, Libya, Morocco, Mozambique, Nigeria, Namibia, Sudan, Tunisia, Zambia, and Zimbabwe (Puska 2007). China supplies significant amounts of weapons to states with critical resources that maintain strong trading ties with China However, there are states such as Ghana or Uganda which are not significant in terms exporting critical resources to China, but have strong ties with China. This means that China is also using arms transfers as a means of enhancing its commercial profits.

Regardless of whether arms transfers have a negative or positive effect, they are nonetheless one of Beijing's instruments of economic policy and cementing political ties with African nations. In Nigeria in particular, China willingly provides weapons to the Nigerian state in its battle against insurgents in the oil-rich Niger Delta. Naval patrol boats and arms have been readily supplied by China to help protect oil infrastructure in the Delta against rebel attacks. In 2006, China's state-controlled oil firm, CNOOC negotiated an investment of over $\$ 2$ billion for $45 \%$ of stake in a Nigerian offshore oil field. In addition, 3 months later China invested an additional $\$ 4$ billion in oil infrastructure projects (Mahtani and White 2006). China continues to expand its oil investments in Nigeria, as well as forging closer military ties (arms transfers, military training, high level military cooperation, etc.) with the Nigerian military. In a similar fashion, Zimbabwe's economic importance correlates strongly with its procurement of both small arms and more sophisticated weapons from China. Zimbabwe is endowed with critical minerals holding the second largest deposits of platinum as well as numerous other minerals including gold, copper, uranium, and ferrochrome. As a result of its attractiveness to China, it is able to get both small arms and more sophisticated military jets. The Mugabe regime is aware of the leverage it has over China because of its focus on cementing ties with countries of geo-economic importance. The Zimbabwean state takes advantage of this and is therefore able to procure all sorts of arms and other technology from China. The Zimbabwean air force is armed with $\mathrm{K}$ - jet aircrafts used in training jet fighter pilots and for use in low intensity warfare. The Zimbabwean military is also in possession of 12 FC-1 fighter planes and several military vehicles worth over $\$ 200$ million. In sum, Chinese weapons have been widely dispersed in Africa. A few examples are Chinese weapons in the hands of Chadean rebels fighting to overthrow the regime, or the use of Chinese weapons in wars in Liberia, and Sierra Leone, as well as in many parts of eastern and central Africa.

\section{Peacekeeping Efforts by China}

Thina does not only transfer military equipment on a bilateral basis, but it has given monetary assistance to the OAU/AU Peace Fund in order to enhance the organization's ability to resolve African conflicts. Accordingly, in 1999 it donated $\$ 100,000$ to the OAU Peace Fund and again in 2000 an additional $\$ 200,000$ 
was donated to the OAU Peace Fund (Rothberg 2015). China's rationale was to show its full support for peacekeeping efforts by Africans themselves, as well as to express its admiration for the organization's continued maintenance of peace and stability in the continent. China's support of the OAU has been regular and generous, as well as varied in terms of funds and equipment. In 2003 and 2005, respectively, China donated $\$ 300,000$ and $\$ 400,000$ to the $\mathrm{AU}$ as an expression of its commitment to African peacekeeping efforts (Agubamah 2014). There is a marked increase in China's donations to African peacekeeping efforts when one takes into account its 1999 and 2000 donations of $\$ 100,000$ and $\$ 200,000$ respectively (Chau 2007). It has since 1990 participated in UN Peacekeeping Operations (UNPKO) several of them in African countries. It is currently, or has been, involved in the following UN Peacekeeping Operations:

1. Democratic Republic of Congo (MONUC, established in 1999) with China supplying 218 troops, and 12 military observers;

2. Ivory coast (UNOCL, established in 2003) with China supplying seven military observers;

3. Liberia (UNMIL, established in 2003) with China supplying 565 soldiers, 18 police, and three military observers;

4. Ethiopia and Eritrea (UNMEE, established in 2000) with China supplying seven military observers; and

5. Western Sahara (MINURSO established in 1991) with China supplying 13 military observers.

In China's overall peacekeeping role in Africa, Chinese troops, or military observers are accordingly involved in humanitarian assistance, protection of human rights, national security reform, national police training, formation and restructuring of militaries, as well as functions of disarmament, demobilization, repatriation, resettlement, and reintegration (DDRRR). These functions are quite the opposite of the negative effects some of its arms transfers are having or have had on civil strife within these same countries where Chinese troops, police, or observers are operating.

Chinese contributions to peacekeeping in Africa are steady, consistent, and expanding. For example in the DRC it contributed 218 out of about 1,600 troops, in Liberia 565 out of about 14,000 troops, and in Ethiopia and Eritrea seven out of the 202 military observers. Most of China's peacekeeping personnel are military troops with expertise in various tasks and functions. While many play a defensive role of UN installations, personnel, and civilians, others have expertise in engineering, logistics, and health care. Those with engineering skills are often engaged in the construction of roads, bridges, camps, and digging of wells for water. Most of the troops that China contributes to peacekeeping are engineers, transportation experts, and medical staff. In the DRC, 175 of the 200 Chinese peace-keepers were engineers, in addition to 40 
medical personnel (SAFERWORLD 2011). In other words, China's view of peacekeeping has a heavy focus on building infrastructure, providing medical care, and overall humanitarian assistance, as a way to promote its national interest, cement its economic relationship with African states, project an image of non-interference and a responsible major power in the international system (Fung 2016). This expanding role of China beyond the geo-economic objective of pursuing resources and profits is becoming a normal aspect of its foreign policy in the continent.

While on the one hand China's arms transfers are linked to civil strife and bloodletting, they are on the other hand used in peacekeeping operations. It could be argued that Chinese arms supplies to African peacekeeping troops involved in AU or UN peace-keeping operations play a positive role of improving peace and security. For example, Chinese supplied arms have been used in peace-keeping by Zambian troops in Sudan. China has consistently given its support to AU peacekeeping efforts and has made it part of its policy orientation towards Africa. In China's 2003 FOCAC Addis Ababa Action Plan it was stated this way:

"We are resolved to step up cooperation and work together to support an even greater role of the United Nations, the African Union and other sub-regional organizations in Africa [It promised to] provide, within the limits of its capabilities, financial and material assistance as well as relevant training to the Peace and Security Council of the African Union. In order to strengthen capacity of African states to undertake peacekeeping operations, we look forward to the strengthening of China's cooperation with African states and sub-regional organizations in the areas of Logistics" (Forum on China-Africa Cooperation, Addis Ababa Action Plan, 2004-2006, 222).

Again, in the 2009 FOCAC Meeting, China reiterated its willingness to continue support for AU Peace-keeping and conflict resolution. In January 2010, as part of China's initiative, the UN Security Council deliberated on how best to maximize peacekeeping by the UN and sub-regional organizations. The Chinese Ambassador to the UN, Zhang Yesui, specifically underscored the need for the international community to aid African efforts at peace-keeping. He stated that:

"The African Union and sub-regional organizations in Africa have been committed to resolving hotspot issues in Africa through good offices and peacekeeping operations, but their efforts are constrained due to deficiencies in funding and capacity building. We support the establishment and deepening of the strategic partnership between the United Nations and the African Union in maintaining peace and security in Africa" (HE Ambassador, Zhang Yesui, UNSC 2010).

China's previous rigid opposition to UN Peace-Keeping has softened since the late 1990s. It realized that Chapter VII UN Peace-keeping had become outdated 
when examined in the light of situations in war ravaged countries of the DRC and Liberia in 2003. The brutality, carnage, and atrocities associated with the wars of the mid-1990s to early 2000s, made it necessary not just to limit peace-keeping to selfdefense but rather to occasionally engage in peace-enforcement expressed in rapid and effective intervention to save civilian lives and even prevent further escalation of conflict. However, China's geo-economic interests at times stand in the way of allowing UN interventions in all countries. For instance, in 2006 China did not give its support for UN peace-keeping expansion in Sudan under UNMIS. It was only after a great deal of pressure from the international community, and its likely negative effect on the Olympic Games hosted by China in 2008, that it acquiesced to the wishes of the United Nations. At the same time, its contribution to peace-keeping in terms of numbers of troops and financial contribution surpassed that of the other great powers. In 2010 China's UN peace-keeping contribution reached \$300 million (SAFERWORLD 2011). By 2010 the majority of Chinese peace-keepers were deployed in African countries such as Mozambique, Sierra Leone, Liberia, the DRC, Cote d'Ivoire, and others.

Influenced by its non-interference policy, China's peacekeeping troops largely play a "supportive role" of building infrastructure, providing medical, logistical, and transport support. China plays a very intensive and extensive peace-keeping role in the $\mathrm{DRC}$, but at the same time it is a purveyor of small arms that are responsible for a great deal of the ethnic carnage, especially in eastern DRC. For instance, within MONUC China takes the lead role in military observer functions. China is so serious about peace-keeping that it has a Civilian Peace-Keeping Police Training Center to train Chinese police officers to be deployed to UN missions. It also established a PeaceKeeping Affairs Office in December 2001. In 2009, it further set up a new peacekeeping center for the training of Chinese military peace-keepers.

China has been heavily involved in peacekeeping activities even in a non-geoeconomic country like Liberia. The UN Mission in Liberia established in 2003 focused on disarmament, demobilization, rehabilitation, and reintegration (DDRR) with the specific objectives of security sector reform, national police training, and a restructured Liberian army. The Chinese peace-keepers are mainly involved in infrastructure development and medical care. In July 2010 China deployed peace-keepers in Liberia numbered 585 strong, the fifth highest behind Pakistan, Nigeria, Bangladesh, and Ghana. The Chinese provide the main source of transportation for the peace-keepers. They transport not just peacekeepers, but fuel, water, and other essential items around Liberia. In the area of infrastructure rehabilitation, Chinese engineers have been busy upgrading roads and bridges, and with the maintenance of runways at airports around the country. By 2010, Chinese engineers along with other peace-keeping forces had rehabilitated hundreds of miles of road networks and bridges. In medical work, Chinese medical staff have provided basic health care to several town and villages, and also assisted in building local medical capacity (UNMIL 2010). Chinese police have also worked very hard on beefing up community security through the training of local Liberian police to effectively combat armed robbery, riots, and violent protests. The Chinese contingent has been especially commended for its efficiency and effectiveness in Liberia. 
China is actively involved in peace-keeping in Africa for a number of reasons. Since peace-keeping is a multilateral effort, it is a way for China to show that it supports cooperative solutions to global security problems, especially ones that are relevant to Africa (Richardson 2011). Involvement at the UN level helps China boost its influence not just within this world body, but also among African nations. In other words, peace-keeping helps boost China's image as a responsible country that is actively engaged in promoting a peaceful and harmonious world. Its focus on Africa creates a positive image of itself among African nations at the UN and beyond (Fung 2015). With peace-keeping it enhances its multilateral and bilateral diplomacy in the international system. It has become the only Security Council member that does not hesitate to send its peacekeeping troops to troubled spots like the DRC, Sudan, or Liberia, among others (Yao 2016). Its willingness to deploy troops in African states counters the negative image created by its arms sales to despotic regimes and zones of conflict. Additionally, its active involvement in aid, trade, investment, and peacekeeping in Africa increases its geo-economic presence all over the continent. According to a report by SAFERWORLD in January 2011:

"In some more general ways, peace-keepers do serve China's economic interests: they promote peace in countries where Chinese banks and commercial actors have made significant investments and have an interest in restoring stability. They also improve bilateral relations with the governments that have given their consent to peacekeeping missions" (76).

China is even using peacekeeping to interact with other militaries around the world within African nations. In Liberia it interacted with Indian, Pakistani, Nigerian, and other military troops. Liberian President Ellen Johnson-Sirleaf commended Chinese peace-keepers for not only enhancing the peace and security of Liberia, but for also contributing to its postwar reconstruction in the form of infrastructure development and helping to build medical capacity in the country.

China's involvement in peacekeeping in developing countries helps provide a sense of global legitimacy to peace-keeping operations since it is the only great power that is not viewed as being under the influence of the US and other Western powers. The Western powers are often viewed by many developing countries as simply out to enhance and even impose their agenda on smaller or weaker nations. It is perhaps only in Sudan that China is not viewed as legitimate or neutral because of its close geo-economic ties and extensive vested interests with the Khartoum regime. Another weakness in China's peacekeeping role is the fact that it is rigidly state-centric in its peacekeeping approach. Beijing's belief that only the state or incumbent regime can be legitimate alienates rebel factions or opposition groups within countries at war. It is not surprising that Chinese workers have been the victims of kidnapping and even massacres by rebel groups in conflict areas. China tends to deviate from guidelines set by the rest of the world regarding aid, trade, and investment. It is the same with its approach to peacekeeping. For instance, China is rigidly opposed to any form 
of imposition on countries undergoing post-conflict reconstruction, especially an externally imposed and predetermined model of political and economic governance. According to Chinese scholars what is most important is not just the promotion of democratic governance, but the reduction of poverty and ending unemployment. The rationale is that poverty is associated with instability therefore the long-term objective of peace-building must be to ensure human security by focusing on alleviating both poverty and unemployment.

\section{Summary and Conclusions}

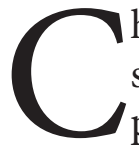

hina's engagement with Africa is multipronged and predicated on a geostrategy of geopolitical objectives with the primary focus on strengthening political ties with all states in Africa, and geo-economic objectives with the principal focus on access to Africa's resources. Both objectives are partly achieved by the seemingly contradictory policies of arms sales which generate profits for China, produce dependence by African states, and thereby enhance stronger political ties, and peacekeeping/peacebuilding activities by China which equally strengthen political ties with African states, but also give China a good image in the world. It is rather obvious that one of the anomalies of China's foreign policy toward Africa is the contradiction between its arms transfers to Africa on the one hand, and its peacekeeping activities on the other. There is a direct clash between monetary support for the AU, deployment of troops to achieve peace in areas of civil strife and interfering in Africa's conflicts through arms transfers. Chinese small arms are used in many of Africa's wars. During the Darfur "genocide" weapons used to commit atrocities against the people of Darfur were supplied by China. The irony is that the United Nations Mission in Sudan (UNMIS) included as many as 446 of the 900 soldiers, 9 of the roughly 660 police, and 14 of the 599 military observers. Similarly, during the war between Ethiopia and Eritrea China was known to have supplied both sides with weapons. However, the United Nations Mission in Ethiopia and Eritrea (UNMEE) established in July 2000, included a Chinese contribution of 7 out of the 202 military observers. Moreover, China is accused of supplying weapons to the Democratic Republic of Congo, while at same time contributing troops to the UN Mission in DRC (MONUC) in its support of disarmament, demobilization, repatriation, resettlement, and reintegration (DDRRR). China contributed 218 of the 16,594 soldiers and 12 of the 713 military observers in that conflict.

While China is not the only country to support both conflict resolution and weapons transfers in war-torn societies, its small arms have nonetheless contributed to protracted wars and bloodletting. In fact, China has been implicated in the Ivorian, Liberian, and Sierra Leonean conflicts because of the role played by Chinese firms smuggling small arms to rebels and mercenaries thereby prolonging and even exacerbating those conflicts. Arms transfers to developing countries never contribute to peace. Therefore one can conclude that China's non-interference policy is calculated to: (1) distance itself from the colonial legacy of the Western countries in Africa; (2) camouflage the aggressive pursuit of African resources and deflect attention from such 
aggressive behavior while presenting an image of China being different from the West; and (3) shroud the fact that Chinese military personnel are ready to do battle and have even done so in Sudan, the Niger Delta of Nigeria, and the DRC. These points make China's longstanding policy of non-interference in Africa tenuous. In particular, China's arms transfer and peacekeeping policy in Africa is schizophrenic because it supports the AU peacekeeping efforts with funds, while at the same time supplying weapons to oppressive authoritarian regimes, effectively contributing to small arms proliferation through its modestly priced weapons, militarizing the African continent.

The danger in China-Africa relations is the fact that China could end up being a role model for the continent furthering human rights violations that could escalate into civil strife. Perhaps the most important concerns related to China's peacekeeping activities in Africa is reconciling its historical record with two fundamental concepts found in the definition peacekeeping; protection and promotion of basic human rights for individuals, the core values and primary goals of UN peacekeeping operations.

China has not fared well on the international scene, earning criticism for its suppression of human rights defenders, control, intimidation, and harassment of lawyers that take politically sensitive cases or seek redress of abuses of power at the hands of government officials, ethnic discrimination, and severe religious repression of Muslim Uyghurs in Xinjiang, mass rehousing and relocation policies in Tibet, and suppression of Hong Kong's "Occupy Central Movement," just to name a few.

In Africa, China is already playing out its human rights violations in places like Sierra Leone, where a mass and forced relocation of employees was carried out by the nation's largest mining employers. The families of the workers were forced to settle in an arid area that does not support productive agriculture. The reports of forced labor in mining sectors, poor safety conditions, long work schedules of up to 18 hour shifts, and anti-union activities enforced by Chinese companies in countries like Eritrea, Zambia, and Sudan, among others. The UN often points out that while China repeatedly calls for political solutions to conflict situations in African states, as an influential member of the UN Human Rights Council, it regularly votes to prevent scrutiny of serious human rights abuses in the continent and around the world. The persistence of human rights abuses in a country eventually results in political instability and human insecurity in all its various forms.

China's domestic policy emphasizing a "harmonious society" has been incorporated into its foreign policy toward Africa. What began as a policy to reduce inequalities and social injustice has now taken on a new meaning. "Stability at all costs" has become the overarching objective. Observers claim the government uses the ideology to justify suppression of dissent and tightening controls on information inside China. Extending and superimposing that ideology in Africa, China is assisting some African regimes like the one in Ethiopia in controlling and monitoring the use of the internet by its people. China has also helped the Zimbabwean regime of Mugabe in jamming the radio broadcasts of its opposition party.

While China seems to have made impressive strides in African security and peacekeeping activities through its financial and military assistance to the African Union and UN peacekeeping activities, its priority in Africa is still geo-economic 
interests or economic ties with African states. Because bilateral economic activities are the greatest focus of China in Africa, peacekeeping and security issues have not yet been discussed with sub-regional organizations like the Economic Community of West African States (ECOWAS) in West Africa. Outright or significant commitment by China for a more effective African Union or an African security force may be slow in coming. However, some Chinese scholars have proposed the idea of an African Peace Fund as a key condition for more effective African peacekeeping efforts. China would most likely prefer to work with the UN in its efforts to contribute to African peace and security. While African sub-regional organizations and the AU can collectively put pressure on China to do more in the area of security and peace in Africa, it appears that China will continue to improve its record on peacekeeping via the UN and its peacekeeping missions in Africa as a way of counteracting the accusations that it is flooding Africa with small arms that are used in many of the ongoing conflicts.

The current levels of China's peacekeeping activities in Africa have had a positive impact because of the level of infrastructure development and medical work performed by Chinese peacekeepers. However, some of the potential obstacles to an expanded Chinese peacekeeping effort would be: (1) the issue of what constitutes legitimate intervention; and (2) China's role in arms transfers that help fuel conflicts in contrast to its peacekeeping activities. Positive developments are that China is becoming more flexible with regard to the legitimacy of UN peacekeeping interventions, and it is at times even advocating within the UN Security Council use of peace-enforcement in situations of gross violations of human rights and humanitarian crisis.

While China supplies a significant number of weapons to states with critical resources with which it maintains strong trading ties, there are also states such as Ghana or Uganda which are not significant in terms of exporting critical resources to China, but maintain strong military ties with China. This means that China is also using arms transfers as a means of enhancing its commercial profits. Arms transfers whether they generate positive or negative effects are simply part of the multipronged diplomatic strategy of China toward Africa. Other dimensions of China's multiple diplomacy are in the areas of aid, trade, investment, health education, and culture. The arms transfer sector is increasing in scope but still lags far behind the aid, trade, and investment strategy. Arms transfers therefore, play the dual role of consolidating relationships/ties with African states, and to some extent, acting as a commercial end in itself.

Finally, the argument can be made that because African armies are poorly equipped and underfunded, Chinese military aid is beneficial to them because it helps uphold the internal integrity, if not territorial integrity of African states. However, on a more critical level, the virtual lack of interstate wars among African states results in regimes using weapons for self-preservation purposes. Such was the case in Guinea. Overall, China is likely to expand and intensify its military relationships with Africa via arms transfers, military attaches, high level military exchanges and meetings, and even joint military exercises.

On a more critical reflection, the African security implications of China's seemingly contradictory role in Africa is manifested in a rhetoric of non-interference 
and peace-building, contradicted by the proliferation of light and inexpensive weapons implicated in some of the most serious cases of bloodletting on the continent. It could be argued that as China widens its engagement with African states it will continue to consolidate military agreements, and engage in more arms transfers on a continent that already has a strong potential for the eruption of more conflicts related a combination of gross inequalities, ethnic rivalry and diversity, and the absence of the rule of law, as well as a strong culture of coups, civil wars, and other forms of civil strife. While it is true that China is not the only great power supplying weapons to African states, the affordability of Chinese weapons enables protracted African wars, and their continued proliferation within the continent. This is more likely to be the case in both the near and distant future because China often does not adhere to UN arms embargoes, sanctions against African states, or their diplomatic isolation. Its preoccupation to consolidate its diplomatic ties, and strengthen its partnerships with African states means it often takes an approach different from those of Western states.

\section{References}

Agubamah, Edgar. 2014. "China and Peacekeeping in Africa." International Journal of Humanitarian and Social Science 14 (11 pp.193-197. ).

Alessi, Christopher, and Beina Xu. 2015. "China in Africa." CFR Backgrounds. www. cfr.org/china/china-africa/p9557 (accessed August 15, 2016).

Amnesty International on Darfur. 2012. "Sudan: No End to Violence in Darfur." http://www.amnestyusa.org/research/reports/sudan-no-end-to-violence-in-darfur (accessed August 15, 2016).

Baah, Anthony Y., and Herbert Jauch, eds. 2009. "Chinese Investments in Africa: A Labour Perspective." African Labour Research Network, May 2009. www.cebri.org/ midia/documents/315.pdf

Baker, Benjamin D. 2015. "Chinese Arms Companies are Picking up the Pace in Africa and the Middle East." The Diplomat. www.thediplomat.com/2015/Chinese-armscompanies-are-picking-up-the pace-in-africa-and-the-middle-east (accessed August $15,2016)$.

Bitzinger, Richard A. 1991. Chinese Arms Production and Sales to the Third World. Santa Monica, CA: Rand.

Caldwell, Mark. 2015. SIPRI: "China's Arms Trade with Africa at Times Questionable” $\quad$ www.dw.com/en/sipri-chinas-arms-trade-with-africa-at-timesquestionable/a-18319346 (accessed August 15, 2016). 
Chang, Andrei. 2007. "Chinese Arms and African Oil." SpaceDaily. http://www. spacedaily.com/reports/Analysis_Chinese_arms_and_African_oil_999.html (accessed August 15, 2016).

Chau, Donovan C. 2007. "Political Warfare in Sub-Saharan Africa: U.S. Capabilities and Chinese Operations in Ethiopia, Kenya, Nigeria and South Africa." http://www. strategicstudiesinstitute.army.mil/pdffiles/pub766.pdf (accessed August 15, 2016).

Deen, Thalif. 2005. "Politics: NGOs Blast Security Council for Inaction in Sudan." www.ipsnews.net/2005/03/politics-ngos-blast-security-council-for-inaction-insudan/ (accessed August 15, 2016).

Enuka, C. 2011. "China's Military Presence in Africa: Implications for Africa’s Wobbling Peace." Journal of Political Studies 18 (1): 15-30.

Forum on China-Africa Cooperation, Addis Ababa Action Plan, 2004-2006. http:// www.focac.org/eng/ltda/dejbzjhy/DOC22009/t606801.htm (accessed August 15).

Fung, Courtney J. 2015. "What Explains China's Deployment to UN Peacekeeping Operations?." International Relations of the Asia-Pacific doi:10.1093/irap/lcv020

Fung, Courtney J. 2016. "China's Troop Contributions to U.N. Peacekeeping." www. usip.org/publications/2016/07/26/china-s-troop-contributions-un-peacekeeping

Grant, Jonathan. 2012. "Merchants of Death: The International Traffic in Arms." Origins, Current Events in Historical Perspective 16 (3).

Human Rights First. 2008. "China’s Arms Sales to Zimbabwe." Fact Sheet. https://www. humanrightsfirst.org/wp-content/uploads/pdf/080428-CAH-china-zimbab-arms-fs. pdf (accessed August 15, 2016).

Hyer, Eric. 1992 “China’s Arms Merchants: Profits in Command." China Quarterly 132: 1101-1118.

Klare, Michael. 2014. American Arms Supermarket. Austin: University of Texas Press.

Lynch, Colum. 2012. "China's arms exports flooding sub-Saharan Africa." The Washington Post (WP Com (US) https:www://washingtonpost.com/world/nationalsecurity/chinas-arms-exports-flooding-sub-saharan-africa/2

Mahtani, Dino, and David White. 2006. "China in Move to Gain Foothold in Nigerian Oilfields." Financial Times, April 27. http://www.ft.com/cms/s/0/bc85fc3e-d58a-11da93bc-0000779e2340.html\#axzz4HRGK7UVO (accessed August 15, 2016). 
McPartland, Ben. 2012. "China's Presence Grows in Murky World of Arms Trading." http://www.france24.com/en/20120307-china-arms-trade-africa-sudan-usa-ukbusiness-military (accessed August 15, 2016).

Mullen, Jethro. 2016. "China's Weapons Sales to Other Countries are Soaring." CNN Money, February 22. money.cnn.com/2016/02/22/news/china-arms-exports-rising/

Pierre, Andrew J. 1982. The Politics of Global Arms Sales. Princeton, NJ: Princeton University Press.

Puska, Susan. 2007. "Military Backs China’s Africa Adventure." Asia Times. Http:// www.atimes.com/atimes/china/if08ad02.html (accessed August 15, 2016).

Richardson, Courtney J. 2011. "A Responsible Power? China and the UN Peacekeeping Regime." International Peacekeeping 18 (3): 286-297.

Rothberg, Robert I. 2015. "China Joins African Peacekeeping." www.chinausfocus. com/peace-security/china-joins-african-peacekeeping

SAFERWORLD REPORT 2011: Chinese Growing Role in African Peace and Security. http://www.saferworld.org.uk/resources/view-resource/500-chinas-growing-role-inafrican-peace-and-security (accessed August 15, 2016).

Sanders, Ralph. 1990. Arms Industries: New Suppliers and Regional Security. Washington, DC: National Defense University.

Schelling, Thomas C. 2008. Arms and Influence. New Haven, Conn. Yale University Press.

SIPRI Yearbook. 2011. Oxford University Press on behalf of Stockholm International Peace Research Institute. http://www.sipriyearbook.org/view/9780199695522/ sipri-9780199695522.xml (accessed August 15, 2016).

Taylor, Ian, and Zhengyu Wu. 2012. "China's Arms Transfers to Africa and Political Violence." Terrorism and Political Violence 25 (3): 457-475.

United Nations Security Council. 2010. http://www.un.org/en/sml (accessed August $15,2016)$.

Wengraf, Lee. "The New Scramble for Africa." International Socialist Review, Issues \#60 Features. isreview.org/issue/60/new-scramble-africa 
Yao, Jianing. 2016. "U.S. Military Observers Visit Chinese Peacekeeping Infantry Battalion in South Sudan." China Military Online, March 22. http://eng.mod.gov.cn/ DefenseNews/2016-03/22/content 4647228.htm

Young, Tom. 2016. Readings in the International Relations of Africa. Bloomington: Indiana University Press. 